\title{
巨大間脳下垂体腫瘍に対する手術戦略についての検討 Consideration of surgical strategy for giant pituitary tumors
}

\author{
大畑 裕紀 森迫 拓貴 一ノ瀬 努 後藤 剛夫
}

大阪市立大学大学院医学研究科 脳神経外科

はじめに

近年、傍鞍部病変に対しては経鼻内視鏡手術が基本ア プローチとなっている。一方で著明な側方進展を伴う病 変に対しては経鼻内視鏡手術と経頭蓋手術を組み合わせ た摘出を考慮する必要があり、腫瘍の性質、局在、大き さにより症例毎に緻密な手術戦略を計画することが重要 である。巨大間脳下垂体腫瘍に対する当院での手術戦略 について報告する。

\section{1. 対象・方法}

2018 年 4 月から 2021 年 2 月に摘出術を施行した長径 $40 \mathrm{~mm}$ を超える間脳下垂体腫瘍で、下垂体腺腫 10 例及び 頭蓋咽頭腫 5 例を対象とした。平均年齢 54.0 歳、平均腫 瘍径 $47.8 \mathrm{~mm}$ 、分葉状 11 例、海綿静脈洞進展 8 例であっ た。手術到達法は、病変が正中に位置した 9 例に対して は経鼻内視鏡手術単独で摘出を、病変が内頚動脈や動眼 神経、後交通動脈を超えて側方進展を有した 5 例には経 鼻内視鏡下と経頭蓋顕微鏡下の同時手術で摘出を、右前 頭葉、脳幹前面と 2 ヶ所に主座を置く再発頭蓋咽頭腫の 1 例では経鼻内視鏡下と経頭蓋顕微鏡下の二期的な摘出 を行った。

\section{2. 結 果}

腫瘍摘出度は 10 例 $(66.7 \%)$ で肉眼的全摘出、5例 (33.3\%) で覀全摘出であった。術後視機能は 4 例 (26.7\%) で改善、10 例 (66.7\%) で不変、1 例 (6.7\%)で 悪化を認めた。全例で術後髄液漏を来さなかった。その 他合併症は 2 例 (13.3\%) で穿通枝梗塞、3 例 (20\%)で動 眼神経不全麻痺、2 例 (13.3\%)で外転神経不全麻痺を認 めた。

\section{3. 症例}

症例提示 1 :

34 歳女性、他院で 11 歳時から複数回の手術、放射 線療法後の再発頭蓋咽頭腫で、右前頭葉、脚間槽と 2 ヶ所に病変を認めた。2 ヶ所の病変は連続性を認め なかったため、まず正中偏位を伴う右前頭様囊胞性病 変に対して経頭蓋顕微鏡下腫瘍摘出術を施行し、二期 的に脚間槽病変に対して経鼻内視鏡下腫瘍摘出術を施 行した。一期目の手術時に後交通動脈と強く癒着して いた部位のみ腫瘍を残存させて、二期的摘出術で腫瘍 は亜全摘出を行った(Fig. 1)。

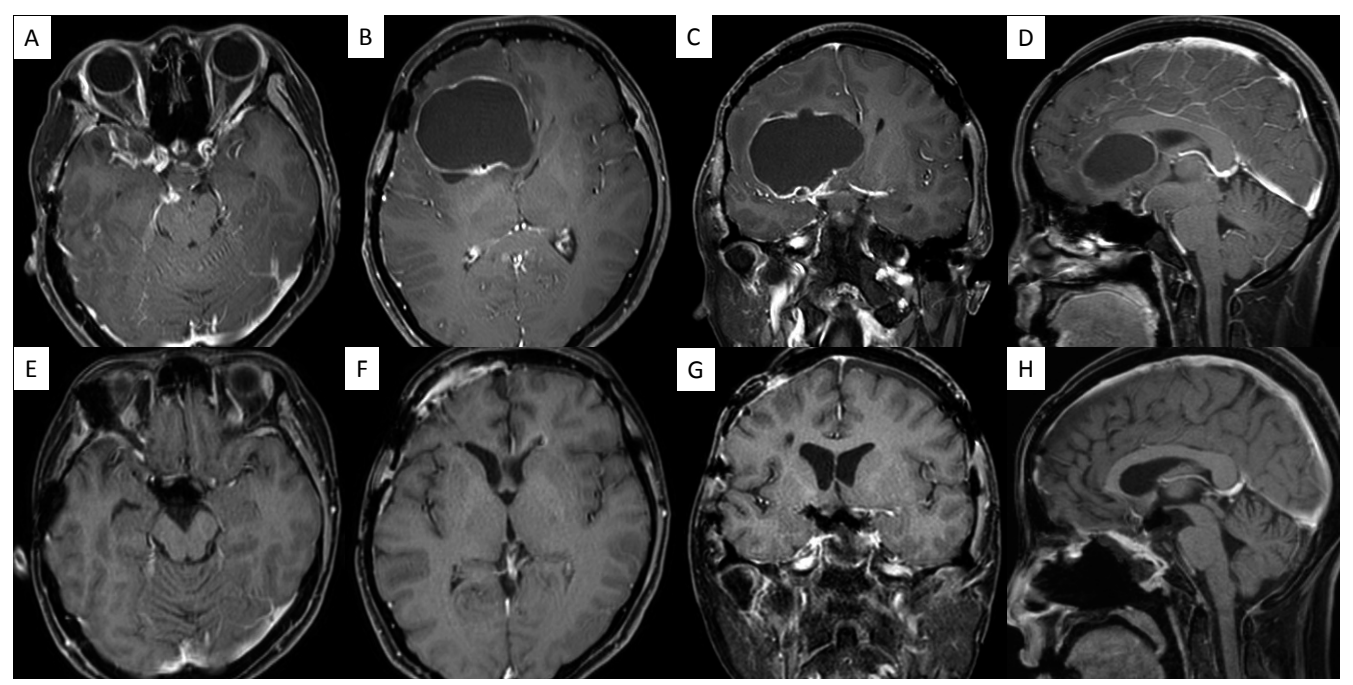

Fig. 1. Preoperative and postoperative MR images of Case 1 A and B: Preoperative contrast-enhanced T1-weighted MR images in axial section. C and D: Preoperative contrast-enhanced T1-weighted MR images in coronal and sagittal section. $E$ and F: Postoperative contrast-enhanced T1-weighted MR images in axial section. $\mathrm{G}$ and $\mathrm{H}$ : Postoperative contrast-enhanced T1-weighted MR images in coronal and sagittal section. 
症例提示 2

46 歳男性、糖尿病性ケトアシドーシスで発症した $\mathrm{ACTH}$ 産生下垂体腺腫で、鞍内から鞍上部、左前頭 葉、脚間槽へと分葉状に進展を認めた。大型分葉状下 垂体腺腫に対する二期的な摘出は残存腫瘍からの術後 出血のリスクが高いと考え、一期的に可及的な摘出を 目指して経鼻内視鏡下経頭盍小開頭内視鏡下同時腫瘍 摘出術を施行した。易出血性で非常にやわらかい腫瘍 で、経鼻、経頭蓋からそれぞれ可及的に腫瘍の摘出を 行った。特に内䅡動脈周囲では死角を補い合うことで 安全に摘出が可能であった。腫瘍は $90 \%$ 程度の摘出 を行い、十分に止血を確認して終了した(Fig. 2)。
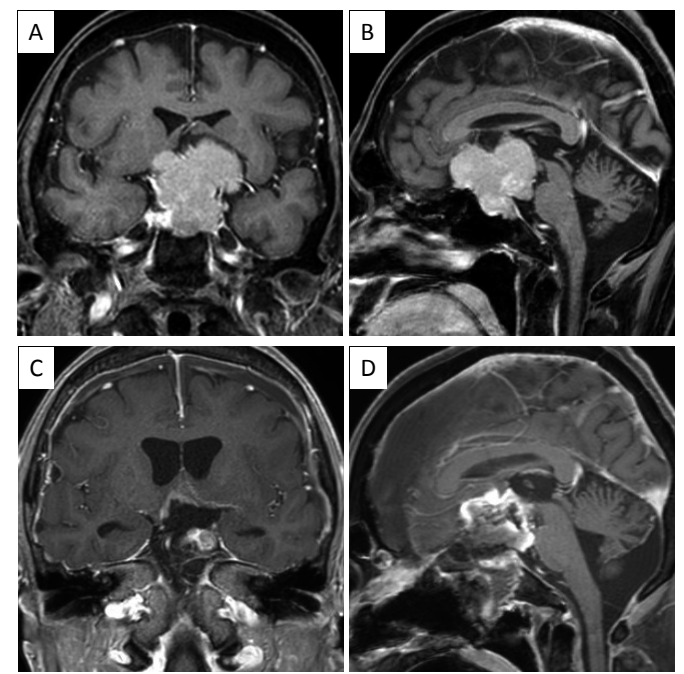

Fig. 2. Preoperative and postoperative MR images of Case 2 A and B: Preoperative contrast-enhanced T1-weighted $M R$ images in coronal and sagittal section.

$\mathrm{C}$ and D: Postoperative contrast-enhanced T1-weighted MR images in coronal and sagittal section.

\section{4. 考 察}

当院での巨大間脳下垂体腫瘍に対する手術戦略は拡大 経蝶形骨洞到達法を軸とし、著明な外側進展を有する症 例では経頭蓋での顕微鏡や内視鏡を併用した多段階手 術、もしくは同時手術を行う方針としている。

経鼻経頭蓋同時手術は 1984 年にLoyo らが巨大下垂 体腺腫に対する有用性を報告している ${ }^{1)}$ 。以降、頭蓋底 腫瘍、傍鞍部腫瘍への有用性が報告されるようになっ た ${ }^{2)-9)}$ 。2016年には永田らが頭蓋咽頭腫に対する経鼻 内視鏡下経頭蓋小開頭内視鏡下同時手術の有用性を報告 している ${ }^{8)}$ 。

経鼻経頭蓋同時手術は多段階手術と比して、下垂体腺 腫において腫瘍の切除率の向上に伴う術後出血のリスク を低下させる点、頭蓋咽頭腫においてなるべく一塊とし た腫瘍摘出を可能とする点で有用である ${ }^{8) 、 9) 。 さ ら に は ~}$ 死角を補いあうことで確実な止血を得られ、頭蓋内外か
ら硬膜欠損部を形成することで髄液漏のリスクを減じう る $^{6)}$ 。

$40 \mathrm{~mm}$ を超える巨大間脳下垂体腫瘍のなかでも、著明 な外側進展を有する頭蓋咽頭腫、下垂体腺腫に対しては 経鼻経頭蓋同時手術の有用性を検討することが必要と考 えられた。

結語

巨大間脳下垂体腫瘍に対する手術戦略は、拡大経蝶形 骨洞到達法を主軸とし、病変が正中に限局していれば経 鼻手術単独で摘出し、著明な外側進展を有する症例では、 安全かつ積極的な病変切除のために経鼻手術と経頭蓋手 術の組み合わせが重要となる。

\section{文献}

1) Loyo M, Kleriga E, Mateos $H$, de Leo R, Delgado A: Combined supra-infrasellar approach for large pituitary tumors. Neurosurgery 14:485-488, 1984.

2) Alleyne $\mathrm{CH}$, Jr., Barrow DL, Oyesiku NM: Combined transsphenoidal and pterional craniotomy approach to giant pituitary tumors. Surg Neurol 57:380-390; discussion 390, 2002.

3) Attia M, Patel KS, Kandasamy J, Stieg PE, Spinelli HM, Riina HA, et al: Combined cranionasal surgery for spheno-orbital meningiomas invading the paranasal sinuses, pterygopalatine, and infratemporal fossa. World Neurosurg 80:e367-373, 2013.

4) D’Ambrosio AL, Syed ON, Grobelny BT, Freda PU, Wardlaw S, Bruce JN: Simultaneous above and below approach to giant pituitary adenomas: surgical strategies and long-term follow-up. Pituitary 12:217-225, 2009.

5) Dallan I, Castelnuovo P, Locatelli D, Turri-Zanoni M, AlQahtani A, Battaglia P, et al: Multiportal Combined Transorbital Transnasal Endoscopic Approach for the Management of Selected Skull Base Lesions: Preliminary Experience. World Neurosurg 84:97-107, 2015.

6) Matsuda M, Akutsu H, Tanaka S, Ishikawa E: Significance of the simultaneous combined transcranial and endoscopic endonasal approach for prevention of postoperative CSF leak after surgery for lateral skull base meningioma. J Clin Neurosci 81:21-26, 2020.

7) Matsuda M, Akutsu H, Tanaka S, Matsumura A: Combined simultaneous transcranial and endoscopic endonasal resection of sphenoorbital meningioma extending into the sphenoid sinus, pterygopalatine fossa, and infratemporal fossa. Surg Neurol Int 8:185, 2017.

8) Nagata $Y$, Watanabe T, Nagatani T, Takeuchi K, Chu J, Wakabayashi T: Fully endoscopic combined transsphe- 
noidal and supraorbital keyhole approach for parasellar lesions. J Neurosurg 128:685-694, 2018.

9) Nishioka H, Hara T, Usui M, Fukuhara N, Yamada S:
Simultaneous combined supra-infrasellar approach for giant/large multilobulated pituitary adenomas. World Neurosurg 77:533-539, 2012. 